\title{
Potential statistical issues in a study comparing postoperative hunger in patients anesthetized with propofol or sevoflurane
}

\author{
Xiaohong Zhao, MD • Yufeng Gao, MD
}

Received: 18 February 2020/Revised: 20 February 2020/ Accepted: 20 February 2020/Published online: 20 April 2020

(C) Canadian Anesthesiologists' Society 2020

\section{To the Editor,}

We read with interest the report of the recent randomized-controlled trial conducted by Besnier et al. ${ }^{1}$ In this study, the authors compared the effects of propofol and sevoflurane on postoperative hunger in outpatients undergoing transvaginal oocyte retrieval and showed that propofol did not promote recovery of hunger. We would like to put forward some potential limitations in their study related to their statistical handling of the data.

The first relates to the authors' statement that "missing quantitative data were simply imputed to the median value of the other group". In our opinion, this method of dealing with missing variables has limitations as it does not adequately consider the variation between different patients. For example, their article does not seem to have reported the incidence of missing values, and missing values count for the primary endpoint. It would be helpful if the authors could report the incidence of missing values, especially the time between the end of anesthesia (EOA) and the recovery of hunger. We also suggest multiple imputation $(\mathrm{MI})^{2,3}$ as a more optimal method of dealing with missing variables. Multiple imputation fills in the missing variables by evaluating the distribution of known variables in the data set and deriving the trusted values between variables. Using MI to manage missing values may reduce the confidence interval width of the conclusions of this study.

This letter is accompanied by a reply. Please see Can J Anesth 2020; 67: this issue.

\section{Zhao, MD · Y. Gao, MD ( $\bowtie)$}

Department of Anesthesiology, Affiliated Zhongshan Hospital of Dalian University, Dalian, Liaoning, China

e-mail: aoias26@163.com
Second, the authors' description (in Table 3) that "plasma levels of ghrelin, leptin, and insulin were sampled immediately before anesthesia and at ten minutes, one hour, and two hours after the EOA" implies that several variables were repeatedly measured four times. Under these circumstances, we recommend that it may be more appropriate to use repeated measurement analysis of variance $^{4,5}$ as opposed to the two-sided Mann-Whitney test that they used. It would also be helpful if the authors could post (perhaps as supplemental content to a letter) a worksheet with the (three peptides) $\mathrm{x}$ (four times) $\mathrm{x}$ (two groups) $\mathrm{x}$ (58 subjects). By this means, other investigators (or the authors themselves) interested in this problem could do the independent analysis that we recommend.

Conflicts of interest None.

Funding statement None.

Editorial responsibility This submission was handled by Dr. Hilary P. Grocott, Editor-in-Chief, Canadian Journal of Anesthesia.

\section{References}

1. Besnier E, Perdrix A, Gillibert A, et al. Postoperative hunger after outpatient surgery in patients anesthetized with propofol vs sevoflurane: a randomized-controlled trial. Can J Anesth 2020; DOI: https://doi.org/10.1007/s12630-020-01584-w.

2. Kraus WE, Bhapkar M, Huffman KM, et al. 2 years of calorie restriction and cardiometabolic risk (CALERIE): exploratory outcomes of a multicentre, phase 2, randomised controlled trial. Lancet Diabetes Endocrinol 2019; 7: 673-83.

3. Li P, Stuart EA, Allison DB. Multiple imputation: a flexible tool for handling missing data. JAMA 2015; 314: 1966-7.

4. Naziruddin B, Iwahashi S, Kanak MA, Takita M, Itoh T, Levy MF. Evidence for instant blood-mediated inflammatory reaction in 
clinical autologous islet transplantation. Am J Transplant 2014; 14 : 428-37.

5. Huypens $P$, Sass $S, W u$ M, et al. Epigenetic germline inheritance of diet-induced obesity and insulin resistance. Nat Genet 2016; 48 : 497-9.
Publisher's Note Springer Nature remains neutral with regard to jurisdictional claims in published maps and institutional affiliations. 